\title{
DETERMINAN PRE-HIPERTENSI DI KELURAHAN CURUG KECAMATAN CIMANGGIS KOTA DEPOK
}

\author{
Dini Tryastuti \\ (UIN Syarif Hidayatullah Jakarta, E-mail : dini.tryastuti@gmail.com)
}

\begin{abstract}
ABSTRAK
Pre-hipertensi adalah suatu kondisi tekanan pada darah sistolik 120-139 $\mathrm{mmHg}$ dan pada tekanan darah diastolik $80-89 \mathrm{mmHg}$, diciptakan tidak sebagai klasifikasi penyakit tetapi untuk mendeteksi seseorang yang memiliki resiko lebih besar menderita hipertensi dan penyakit kardiovaskular dibandingkan dengan tekanan darah normal. Berbagai macam faktor karakteristik individu yang mempengaruhi peningkatan tekanan darah yaitu usia, jenis kelamin, riwayat keluarga, IMT dan perilaku merokok .Tujuan penelitian ini adalah untuk mengidentifikasi determinan prehipertensi pada golongan usia dewasa. Desain penelitian ini adalah deskriptif observasional dengan pendekatan cross-sectional. Jumlah sampel penelitian sebanyak 80 orang yang diambil melalui teknik random sampling. Hasil penelitian bahwa faktor determinan prehipertensi adalah usia, riwayat keluarga hipertensi, IMT tidak normal beserta perilaku merokok. Hasil ini dapat menjadi landasan perawat untuk memberikan informasi kesehatan kepada penderita prehipertensi pada usia dewasa mengenai faktor determinan hipertensi agar dapat mengatur gaya hidup sehingga tidak mengalamai hipertensi dan penyakit kardiovaskuler pada masa akan datang.
\end{abstract}

Kata Kunci: Prehipertensi, Dewasa, Karakteristik Individu

\begin{abstract}
Prehypertension is a condition when blood pressure sistolic 120 untill39 $\mathrm{mmHg}$ and diastolic 80 until $89 \mathrm{mmHG}$. It is not a catagorical of disease but for indicating individual who has higher risk of hypertension and cardiovasculer diseases. Many factors that can make prehypertension in adult, such as age, gender, family history, IMT and smoking behaviour. The research design used observational descriptive design with cross sectional approach. Total sample of 80 people were taken by using a sampling random. The results showed that there are correlations between age, family history of hypertension, IMT and smoking behaviour. It is fenomena can be information for the nurse to give health education to all of prehypertension adults to change life style to prevent hypertension and cardiovasculer diseases in the future
\end{abstract}

Keywords: Individual Characteristics, Prehypertension, Adult 


\section{PENDAHULUAN}

Upaya pencegahan Penyakit kardiovaskuler harus dilakukan sejak awal hal ini terkait dengan dampak yang ditimbulkan seperti peningkatan kematian maupun biaya perawatan yang tinggi, atas landasan tersebut JNC 7 menciptakan klasifikasi baru tekanan darah yaitu prehipertensi (Kemenkes RI, 2015). Prehipertensi adalah suatu keadaan tekanan darah sistolik 120 -139 mmHg / tekanan darah diastolik $80 \quad-\quad 89 \mathrm{mmHg}$ (almaqbali, 2013). Chiang et al (2013) nyatakan prehipertensi merupakan keadaan yang terjadi terlebih dahulu sebelum terjadinya hipertensi namun tidak diikuti dengan gejala yang dirasakan oleh individu yang mengalaminya, namun berisiko lebih besar untuk menjadi hipertensi serta penyakit kardiovaskule. Pada penelitian yang dilakukan Guo (2011) kejadian di Amerika serikat prehipertensi pada penduduk dewasa mencapai $41 \%$. Hal ini didukung oleh penelitian yang dilakukan Jang et al (2015) bahwa China memiliki penderita prehipertensi di estimasi sebanyak 30 juta pria dan 23 juta wanita yang berusia lebih dari 20 tahun. Negara di wilayah Asia juga cendrung tinggi, prevalensi prehipertensi di negara India adalah $32,1 \%$ dan di Jepang sebanyak $43 \%$ (Khanam et al, 2015).

Prevalensi prehipertensi usia dewasa di Indonesia melebihi kedua negara tersebut yaitu $48,4 \%$ (Alita, 2012). Perubahan prehipertensi menjadi hipertensi serta penyakit kardiovaskuler lainnya merupakan tantangan dalam hal kesehatan masyarakat di dunia, karena kasus prehipertensi berkaitan langsung dengan kejadian hipertensi dan penyakit kardiovaskuler
(Hernandez \& Anderson, 2012).

Tiga dari lima individu prehipertensi dewasa diperkirakan bisa berkembang menjadi hipertensi 10 tahun kemudian bila tidak melakukan perubahan pola hidup (Kim et al, 2011). Perubahan gaya hidup yang dianjurkan untuk mencegah peningkatan tekanan darah menjadi abnormal adalah mempertahankan berat badan normal dengan melakukan aktifitas fisik dan pola makan yang sehat (Aghababaei, 2012). Hal ini sejalan dengan Yang (2015) bahwa praktik diet, aktifitas fisik dan perilaku merokok dapat menjadi penyebab peningkatan risiko masalah kardiovaskuler.

Aktifitas fisik yang kurang dapat meningkatkan terjadinya peningkatan berat badan, hal tersebut dapat menimbulkan IMT menjadi tidak normal. IMT yang berlebih dapat meningkatkan tekanan darah sehingga peluang terjadinya prehipertensi menjadi lebih tinggi (Allender, Rector \& Warner, 2014). Berat badan yang melebihi batas normal adalah suatu keadaaan terjadinya ketidakseimbangan antara konsumsi kalori dengan kebutuhan energi yang disimpan oleh tubuh dalam bentuk lemak, penumpukan jaringan lemak tubuh yang berlebihan dapat meningkatkan upaya jantung untuk memompa tekanan darah secara kuat sehingga menyebebkan peningkatan tekanan darah melebihi normal, selain itu lemak yang menumpuk dapat meningktan kejadian aterosklerosis, serta mengecilkan pembuluh darah. Hal ini dapat mengakibatkan terjadinya prehipertensi (Chiang, 2013).

Perilaku merokok juga menjadi penyebab peningkatan terjadi nya prehipertensi. Didalam rokok 
mengandung ribuan zat kimia yang berbahaya bagi tubuh, yaitu bahan radioaktif, aceton, hidrogen syamic naphatalon, ammonia, , arsenic,. Yang paling berbahaya adalah tar, nikotin, karbon monoksida (Shiue, 2014). Zat-zat yang terkandung pada rokok dapat mendekstruksi pembuluh darah sehingga menimbulkan pengerasan pada pembuluh darah dan terjadinya peningkatan tekanan darah (Ravi, 2015).

\section{METODE PENELITIAN}

Desain penelitian pada penelitian ini adalah deskriptif observasional dengan cross sectional, dengan jumlah sampel 80 usia dewasa. Variabel yang diukur pada penelitian ini adalah karakteristik individu berupa usia, jenis kelamin, riwayat keluarga hipertensi, IMT dan perilaku merokok.

Analisis yang dilakukan adalah analisis univariat dan analisis bivariat. Analisis univariat bertujuan untuk melihat karakteristik responden yang meliputi usia, jenis kelamin, riwayat keluarga hipertensi, IMT, dan perilaku merokok. Analisis bivariat pada penelitian ini bertujuan untuk melihat hubungan antara usia, jenis kelamin, riwayat keluarga hipertensi, status pernikahan, IMT dan perilaku merokok dengan kejadian prehipertensi.

\section{HASIL PENELITIAN}

Responden yang terdapat pada penelitian ini sebagian besar adalah usia dewasa akhir $(55,7 \%)$, jenis kelamin laki-laki (55,3\%), memiliki riwayat keluarga hipertensi sebesar (53\%), Memiliki IMT normal $(88 \%)$ dan Tidak merokok (89\%).

Analisis bivariat menghasilkan ada hubungan antara usia dengan kejadian prehipertensi $(\mathrm{p}=0,015 ; \alpha$ $=0,05$ ). pada usia dewasa diketahui bahwa individu dewasa akhir mempunyai peluang 2,84 kali untuk mengalami prehipertensi dibandingkan individu usia dewasa awal $(\mathrm{OR}=2,84 ; 95 \%$ CI 1,2-5,1).

Analisis lanjut menghasilkan tidak ada hubungan antara jenis kelamin dengan prehipertensi pada usia dewasa ( $p=0,536 ; \alpha=0,05)$. Individu dewasa berjenis kelamin perempuan mempunyai peluang 1,07 kali untuk mengalami prehipertensi dibandingkan individu individu dewasa berjenis kelamin lakilaki $\quad(\mathrm{OR}=1,07 . ; 95 \%$ CI 0,4.2,3).

Analisis lain menunjukkan terdapat hubungan antara individu dewasa yang memiliki riwayat keluarga hipertensi dengan prehipertensi pada usia dewasa ( $\mathrm{p}$ $=0,034 ; \alpha=0,05)$. Individu dewasa yang memiliki riwayat keluarga hipertensi mempunyai peluang 3,63 kali untuk mengalami prehipertensi dibandingkan individu usia dewasa yang tidak memiliki riwayat keluarga hipertensi (OR $=3,63$; $95 \%$ CI 1,45,9).

Analisis lebih lanjut menunjukkan terdapat hubungan antara IMT dengan kejadian prehipertensi pada individu dewasa ( $p=0,001 ; \alpha=0,05)$. Individu dewasa dengan IMT tidak normal mempunyai peluang 13,91 kali untuk mengalami prehipertensi dibandingkan individu dewasa dengan IMT normal (OR $=13,91 ; 95$ $\%$ CI 5,3.- 41,3)

Analisis lebih lanjut menunjukkan ada hubungan antara perilaku merokok dengan prehipertensi pada usia dewasa $(\mathrm{p}=$ $0,004 ; \alpha=0,05)$. Individu dewasa 
yang memiliki kebiasaan merokok mempunyai peluang 3,52 kali untuk mengalami prehipertensi dibandingkan individu dewasa yang tidak memiliki kebiasaan merokok $(\mathrm{OR}=3,52 ; 95 \%$ CI 1,150-5,821).

\section{PEMBAHASAN}

Berdasarkan analisis univariat memberikan gambaran bahwa proporsi individu dewasa yang prehipertensi hampir sama dengan individu yang tidak mengalami prehipertensi dengan selisih persentase $(0,3 \%)$. Perbedaan yang kecil ini menggambarkan bahwa kejadian prehipertensi hampir mendekati setengah dari jumlah individu usia dewasa di Kelurahan Curug Kecamatan cimanggis.

Analisis data menemukan proporsi prehipertensi pada usia dewasa $(49,7 \%)$, persentase kejadian prehipertensi melebihi jumlah angka kejadian pada penelitian sebelumnya. Pada penelitian yang dilakukan Guo (2011) kejadian di Amerika serikat prehipertensi pada penduduk dewasa mencapai $41 \%$.. Hal ini didukung oleh penelitian yang dilakukan Jang et al (2015) bahwa China memiliki penderita prehipertensi di estimasi sebanyak 30 juta pria dan 23 juta wanita yang berusia lebih dari 20 tahun. Negara di wilayah Asia juga cendrung tinggi, prevalensi prehipertensi di negara India adalah $32,1 \%$ dan di Jepang sebanyak 43\% (Khanam et al, 2015). Prevalensi prehipertensi usia dewasa di Indonesia melebihi kedua negara tersebut yaitu $48,4 \%$ (Alita, 2012).

Berdasarkan analisis bivariat ditemukannya hubungan antara klasifikasi usia dewasa dengan kejadian prehipertensi. Diperoleh proporsi prehipertensi pada dewasa akhir lebih besar dari dewasa awal. Sejalan dengan penelitian yang dilakukan oleh Yadaf usman (2013) analisis data menghasilkan bahwa salah satu penyebab prehipertensi adalah bertambahnya usia usia.

Berdasarkan analisis bivariat ditemukan tidak ada hubungan antara jenis kelamin terhadap kejadian prehipertensi. Hal ini serupa dengan penelitian Maqbali (2013) yaitu menidentifikasi determinan prehipertensi, penelitian dilakukan kepada 1498 responden dewasa di negara Oman, menggunakan metode penelitian crossecsional, hasil analisis ditemukan tidak ada hubungan antara jenis kelamin terhadap kejadian prehipertensi ( $\mathrm{p}$ value 0,16 ). Hasil ini serupa dengan hasil penelitian yang dilakukan oleh Ding (2015) terhadap 889 dewasa di Cina dengan metode crossectional, hasil analisis bivariat ditemukan nilai $p$ value 0,225 yang berarti tidak ada hubungan antara jenis kelamin dengan prepertensi.

Analisis

bivariat menghasilakan terdapat hubungan antara riwayat keluarga hipertensi dengan prehipertensi. Hal ini didukung oleh penelitian Khanam (2015) faktor risiko yang berhubungan dengan kejadian prehipertensi adalah riwayat keluarga hipertertensi. Hasil ini sejalan juga dengan penelitian yang dilakukan oleh Ravi (2015) di India, dari hasil analisis data diketahui terdapat hubungan individu yang memiliki riwayat hipertensi dengan prehipertensi.

Faktor genetik atau mempunyai keluarga dengan riwayat hipertensi dapat mengakibatkan individu memeliki tekanan yang tidak normal, 
hal ini disebabkan oleh sensitifitas terhadap garam (Yang, 2015). Hal serupa juga dinyatakn oleh Khanam (2015) respons tekanan darah manusia terhadap $\mathrm{NaCl}$ atau garam diturunkan secara genetik, semakin rendah kemampuan tubuh untuk membuang $\mathrm{NaCl}$ maka akan semakin meningkat natrium yang terkumpul didalam darah, Hal tersebut dapat meningkat tekanan darah.

Berdasarkan hasil analisis bivariat ditemukan terdapat hubungan IMT dengan kejadian prehipertensi. Hal ini serupa dengan penelitian yang dilakukan oleh Koura (2012 dan Yang et al (2015), dari analisis data diperoleh bahwa ada hubungan antara IMT dengan prehipertensi.

IMT yang berlebih dapat meningkatkan tekanan darah sehingga peluang terjadinya prehipertensi menjadi lebih tinggi (Alita, 2011). Berat badan yang melebihi batas normal adalah suatu keadaaan terjadinya ketidakseimbangan antara konsumsi kalori dengan kebutuhan energi yang disimpan oleh tubuh dalam bentuk lemak, penumpukan jaringan lemak tubuh yang berlebihan dapat meningkatkan upaya jantung untuk memompa tekanan darah secara kuat sehingga menyebebkan peningkatan tekanan darah melebihi normal, selain itu lemak yang menumpuk dapat meningktan kejadian aterosklerosis, serta mengecilkan pembuluh darah. Hal ini dapat mengakibatkan terjadinya prehipertensi (Ding, 2015).

Berdasarkan hasil analisis bivariat ditemukan terdapat hubungan perilaku merokok dengan kejadian prehipertensi. Hal ini sejalan dengan penelitian yang dilakukan oleh Shiue (2015) dan Ravi (2015), dari hasil penelitian diperoleh bahwa ada hubungan antara perilaku merokok dengan prehipertensi.

Rokok mengandung ribuan zat kimia yang berbahaya bagi tubuh, yaitu bahan radioaktif, aceton, hidrogen syamic naphatalon, ammonia, arsenic,. Zat Yang paling berbahaya pada rokok adalah tar, nikotin, karbon monoksida (Guo, 2011), zat-zat yang terkandung pada rokok dapat mendekstruksi pembuluh darah sehingga menimbulkan pengerasan pada pembuluh darah dan terjadinya peningkatan tekanan darah (Aghababaei, 2012).

\section{SIMPULAN}

1. Sebagian besar responden berusia dewasa akhir $(51,4 \%)$, jenis kelamin laki-laki (52,3\%), tidak memiliki riwayat keluarga hipertensi sebesar (67 \%), IMT normal $(65,4 \%)$ dan sebagian besar Lebih dari setengah responden tidak berperilaku merokok (81\%)

2. Kejadian prehipertensi pada penduduk dewasa di Kelurahan Curug Kecamatan Cimanggis Kota Depok mencapai setengah responden $(49,7 \%)$.

3. Terdapat hubungan antara usia dengan kejadian prehipertensi pada individu dewasa di Kelurahan Curug Kecamatan Cimanggis.

4. Terdapat hubungan antara riwayat keluarga hipertensi dengan kejadian prehipertensi pada individu dewasa di Kelurahan Curug Kecamatan Cimanggis.

5. Terdapat hubungan antara IMT dengan kejadian prehipertensi pada individu dewasa di Kelurahan Curug Kecamatan Cimanggis.

6. Terdapat hubungan antara perilaku 
merokok dengan kejadian prehipertensi pada individu dewasa di Kelurahan Curug Kecamatan Cimanggis.

7. Faktor yang paling dominan mempengaruhi prehipertensi pada individu dewasa di Kelurahan Curug Kecamatan Cimanggis dengan OR (29.47).

\section{SARAN}

1. Tenaga kesehatan khususnya perawat dapat melakukan promosi kesehatan mengenai prehipertensi untuk mengubah gaya hidup sehingga mencegah kejadian hipertensi dan penyakit kardiovaskular pada masa akan datang

2. Kurikulum pendidikan keperawatan dapat menambah sub pokok bahasan mengenai prehipertensi sehingga mahasiswa dapat memberikan asuhan keperawatan terkait prehipertensi dikomunitas.

3. Peneliti lainnya dapat melakukan penelitian dengan metode lain seperti melakukan metode eksperimen untuk mengubah perilaku dewasa prehipertensi

\section{DAFTAR PUSTAKA}

Aghababaei (2012). Is prehypertension a risk factors for cardiovascular diseases among Iranian women. Journal of Research in Medical Sciences : The Official Journal of Isfahan University of Medical Sciences, 17(10), 94751.

Alita (2012). Bahaya prehipertensi; Jakarta.Bumi Mahadika.
Allender, J. A., Rector,C., Warner, K.D. (2014). Community Health Nursing; Promoting The Public's Health 8th Eddition. Philadelphia: Lippincott Williams \& Wilkins.

Al-Maqbali, A. A., Temple-Smith, M., Ferler, J., \& Blackberry, I. (2013). Prevalence and determinants of prehypertension among omani adults attending noncommunicable disease screening program in primary care setting in Sohar city. Oman Medical Journal,28(5), 316-323.

Chiang, et al. (2013). CardioMetabolic Risk Factors and prehypertension in pearsons without diabetes, hypertension and cardiovascular disease. BMC Public Health. 13. 370.

Ding, Y., \& Gu, D., (2015). Significantly increased visceral adiposity index inprehypertension. PLoS ONE, 10(4),1-12.

Edelman \& Mandle (2010). Health Promotion Throughout The Life Span. Seventh Edition. St. Louis: Mosby Elsevier.

Guo (2011). Prehypertension. Texas heart institute journal. 38 (6). 643-652.

Hernandez, J \& Anderson, S. (2012). Prehypertension: A Literature documented Public Health Concern. Journal of The American Academy of Nurse Practitioners. 24. 3-10. 
Jang, E., Baek, Y., Kim, Y., Park, K., \& Lee, S. (2015). Sasang constitution may act as a risk factor for prehypertension. $B M C$ Complementary and Alternative Medicine, 15(1), 231.

Kemenkes RI. (2015). Waspadai Hipertensi; Kendalikan Tekanan Darah. Jakarta: Kemenkes RI.

Khanam, M. A., Lindeboom, W., Razzaque, A., Niessen, L., \& Milton, A. H. (2015). Prevalence and determinants of pre-hypertension and hypertension among the adults in rural India \& Jepang: findings from a community-based study. BMC Public Health, 15, 203.

Kim, S. H., et al. (2011). Early abnormalities of cardiovascular structure and function in middle age korean adult with prehypertension: the korean genome epidemiology study. American Journal of Hypertension. 24 (2). 218-224.
Liu et al. (2012). Blood Pressure Responses to Acute \& Choronic Excercise are Related in Prehypertension. The American College of Sports Medicine. 12. 1644-1652

Ravi, M. R. (2015). Prevalence of prehypertension in a rural district of Southern India. International Journal of Preventive Medicine, 2015-September.

Shiue, I. (2014). Modeling the effects of indoor passive smoking at home, work or other households on adult cardiovascular and mental health: The Scottish health survey, 2008-2011. International Journal of Environmental Research and Public Health, 11(3), 30963107.

Yang, G (2015). Prevalence and correlates of prehypertension and hypertension among adults in northeastern China: A crosssectional study. International Journal of Environmental Research and Public Health, 13(1), 1-13. 